\title{
POTENCY OF CONSORTIUM SYMBIONT MICROBE OF MANGROVE LITTER AS NATURAL PRESERVATIVE FOR TOFU
}

\section{POTENSI BAKTERI KONSORSIUM SIMBION SERASAH MANGROVE SEBAGAI PENGAWET ALAMI MAKANAN TAHU}

\author{
Delianis Pringgenies*, Amelia Cahya Anggelina, Wilis Ari Setyati, \& Ali Djunaedi \\ Department of Marine Sciences, Faculty of Fisheries and Marine Sciences, \\ Diponegoro University, Semarang, 50275, Indonesia \\ *E-mail: pringgenies@yahoo.com
}

\begin{abstract}
Symbiont bacteria from mangrove litter are known to have antimicrobial activity against Staphylococcus aureus. However, only a handful of research has been carried out on microbes as an innovative natural material for preserving food, especially tofu. This research used four species of mangrove litter symbiont microbe, which were cultured as a microbial consortium. The study aimed to determine the potential of consortium microbe as tofu preservatives. The tofu was soaked in the liquid culture of the consortium microbe as a treatment, while for the positive control, it was immersed in tofu using $37 \%$ formalin, and for the negative control, the tofu was not given any treatment. The organoleptic observations on the second day showed that the tofu with all treatment did not change in odor, color, and texture. On the other hand, tofu without treatment became more acidic in odor, with a yellowish color, and showed a softer texture. On the third day, tofu with bacterial microbe treatment had a slight change in odor, the color became yellowish, and the texture was slightly softened. Tofu with formalin treatment did not change in color, but became more solid and extruded formalin odor. Tofu with the consortium microbe immersion treatment had the least amount $\left(6.795 \times 10^{3}\right)$ of total microbe count, compared with the formalin treatment $\left(9.766 \times 10^{3}\right)$ and without treatment $\left(9.766 \times 10^{3}\right)$.
\end{abstract}

Keywords: bacteria symbiont, consortium microbes, mangrove litter, preservative, tofu

\begin{abstract}
ABSTRAK
Bakteri simbion serasah mangrove diketahui memiliki aktifitas antibakteri terhadap bakteri Staphilococcus aureus, namun belum banyak dilakukan penelitian terhadap bakteri yang bersimbion dengan serasah mangrove sebagai inovasi bahan alami untuk mengawetkan makanan khususnya tahu. Pada penelitian ini digunakan bakteri konsorsium dari limbah mangrove. Tujuan penelitian adalah untuk mengetahui potensi bakteri konsorsium sebagai bahan pengawet makanan tahu. Tahu direndam dengan kultur cair bakteri konsorsium sebagai perlakuan, sedangkan untuk kontrol positif dilakukan perendaman terhadap tahu menggunakan formalin 37\%, dan untuk kontrol negatif tahu tidak diberikan perlakuan apapun. Hasil pengamatan organoleptis pada hari kedua menunjukkan bahwa tahu dari semua perlakuan tidak mengalami perubahan bau, warna dan tekstur, sedang tahu tanpa perlakuan mengalami perubahan bau yang lebih asam, warna kekuningan dan tekstur lebih lembek. Hari ketiga, tahu perlakuan bakteri konsorsium sedikit mengalami perubahan bau dan warna kekuningan dan tekstur agak lembek, perlakuan formalin tidak mengalami perubahan warna sama sekali, namun teksturnya semakin mengeras dan berbau formalin. Jumlah bakteri pada tahu yang diberi perlakuan rendaman bakteri konsorsium memiliki jumlah paling sedikit $\left(6,795 \times 10^{3}\right)$ dibandingkan dengan jumlah bakteri pada perlakuan formalin $\left(9,766 \times 10^{3}\right)$ dan tanpa perlakuan $\left(9,766 \times 10^{3}\right)$.
\end{abstract}

Kata kunci: bakteri simbion, limbah mangrove, mikroba konsorsium, pengawetan, Tahu 


\section{INTRODUCTION}

Tofu is a food that is very popular with people in Indonesia and has also been known and consumed in many countries. In Indonesia, tofu is generally consumed as a snack or as an additional side dish. Tofu is made of soybeans and has nutritional value that is beneficial for health. However, tofu that has been produced usually does not have a long shelf life. In open space, tofu can immediately change smell, color, and texture in just one day. This condition makes traders often operate at a loss if the commodity is not immediately sold, which in some cases encourages them to find improper solutions by using formalin as a preservative. Formalin is a solution with a specific use, namely to preserve cadavers. Therefore, using formalin as a food preservative is a dangerous practice, as the solution is highly toxic.

Preservatives are very commonly used as additives for processed food products, including fish products. The purpose of adding these food preservative products is to extend the shelf life of a commodity. Food preservatives can be categorized into natural and artificial or chemical food preservatives. Nitrite, benzoic acid, sulfur dioxide, ascorbic acid, and sprayed curing are potential preservatives used in fishery products (Syamdidi, 2012).

In general, the purpose of adding food preservatives is to inhibit the growth of fooddecomposing microorganisms, extend food shelf-life, maintain nutritional value, taste, smell, and color of food, and improve the visual appearance of food ingredients. The use of preservatives is also expected to give very little to no increase in the production cost and does not affect the price of preserved food (Cahyadi, 2009).

It is known that changes in food quality are caused by the growth of microorganisms. This growth can be inhibited by other microorganisms that have the potential as antibacterial. Symbiotic bacteria from mangrove litter have the potential to be antimicrobial agents and microbial decomposers because they have proven to be potential decomposers of organic waste to decomposer. Included in the list of such symbiont microbes are Pseudomonas sp., Flavobacterium sp., Acinetobacter sp., Bacillus subtilis (Pringgenies et al., 2017). Based on the description above, the purpose of the study was to determine the potential of microbial consortium as a preservative for tofu.

\section{RESEARCH METHODS}

\subsection{Sample Preparation}

The microbial symbiont samples were collected in the mangrove ecosystem in Mangunhardjo, Tugu district, Semarang city. The mangrove litter samples were transported to the laboratory, then the isolation of the microbial symbionts was carried out by dilution. The next steps were to identify the characteristics of microbial colonies, purification of bacteria by isolating microbial symbionts, qualitative tests for microbial symbionts. The results of all these processes showed that the isolate samples had antimicrobial activity against pathogenic bacteria from the species Vibrio alginolyticus, $\quad V$. parahaenolyticus, $\quad V$. vulnificus, V. harveyi, Micrococcus lutheus, Staphylococcus epidhemis, Pseudomonas aeruginosa, E. coli. Microbial identification was carried out using the 16s rDNA Polymerase Chain Reaction (PCR) method. $16 \mathrm{~S}$ rDNA identifies microbial isolates as Pseudomonas sp., Flavobacterium sp., Acinetobacter sp., B. subtilis (Pringgenies et al., 2016).

\subsection{Microbial Sample Antagonistic Test}

One of the four samples of microbial isolates was scratched on the NB (Nutrient Broth) medium to form a line. Then, the second microbial isolate was crossed through a line stroke of the previous microbial isolate in the same media container. The third 
microbial isolate was crossed through line strokes of the previous microbial isolates, still in the same media container. This method ensures that microbial isolates were embedded in contact with each other. The sample isolates were incubated for at least 24 hours, then each microbial isolate was observed for growth. If no inhibition zone is formed, this means that each microbe synchronizes in the resulting consortium.

\subsection{Making Microbial Sample Starter}

Microbial isolates were taken from solid media using inoculation needles, then put in liquid media in a test tube and placed in a shaker at $1400 \mathrm{rpm}$ for $3 \times 24$ hours.

\subsection{Bulk Culture of Microbial Consortium on Liquid Zobell Media}

$500 \mathrm{~mL}$ of liquid media was added to the $50 \mathrm{~mL}$ microbial starter $(12.5 \mathrm{~mL}$ Acinetobacter microbial starter, $12.5 \mathrm{~mL}$ microbial starter Flavobacter, $12.5 \mathrm{~mL}$ microbial starter of Pseudomonas, and 12.5 $\mathrm{mL}$ microbial starter of Bacillus). The samples were then placed on a shaker for $5 \times 24$ hours at a speed of $1400 \mathrm{rpm}$.

\subsection{Microbial Consortium Treatment on Tofu}

The study was conducted on three different tofu samples, namely tofu the consortium microbial immersion treatment, tofu formalin treatment, and tofu without treatment.

Each tofu sample as the test material was weighed up to $100 \mathrm{~g}$. The tofu sample was then soaked in $20 \mathrm{~mL}$ culture of microbial consortium for a few moments, and the entire surface of the tofu is confirmed to be exposed to the solution. Another tofu sample was immersed in a $3.6 \%$ formalin solution as a positive control. All tofu samples were observed for odor, color, and texture every day until changes occur.

\subsection{Microbial Isolation for Total Plate Count (TPC) \\ $9 \mathrm{~mL}$ of sterile fresh water is added} with $1 \mathrm{~g}$ of mashed sample. Next, the mixture is placed in the vortex machine until it becomes homogeneous. The resulting homogeneous solution was taken as much as $50 \mu$, then dropped and leveled on the surface of agar nutrient media. Medium nutrient agar, which had been planted by microbial samples, was then incubated until the microbe develop (24-48 hours). The microbial colonies that have grown on the surface of the nutrient were then counted. The protein knows after the treatment is then analyzed using the Kjeldahl method.

\section{RESULTS AND DISCUSSIONS}

\subsection{Results}

\subsubsection{Organoleptic}

Tofu preservatives were divided into three treatments, namely treatment with bacterial consortium immersion (TKB), formaldehyde (TF) treatment, and no treatment (TTP). The period of research observation lasted for three days. On the first day, the TKB sample was still freshsmelling, white, and was elastic in texture. While the TF sample extruded a distinctive formalin form, it is white and had an elastic texture that tends to be solid. TTP samples had a fresh smell, white, and had an elastic texture. The observation data for the first day is listed in Table 1.

On the second day, the TKB sample was fresh smelling, white, and was elastic in texture. TF sample had a distinctive formalin smell, is white, and had an elastic texture that tends to be solid. TTP sample smelled mildly sour, white, and had an elastic texture.

Observation on the third day found that the TKB sample was smelling mildly sour, with pale yellow coloration, while maintaining elastic texture. TF sample extruded formalin smell, retained white color, and hardened in texture. TTP sample 
extruded foul smell, with yellowish coloration and creamy in texture.

Table 1. Tofu Treatment with Immersion in Microbial Consortium (TKB), Treatment with Formalin (TF), and without Treatment (TTP).

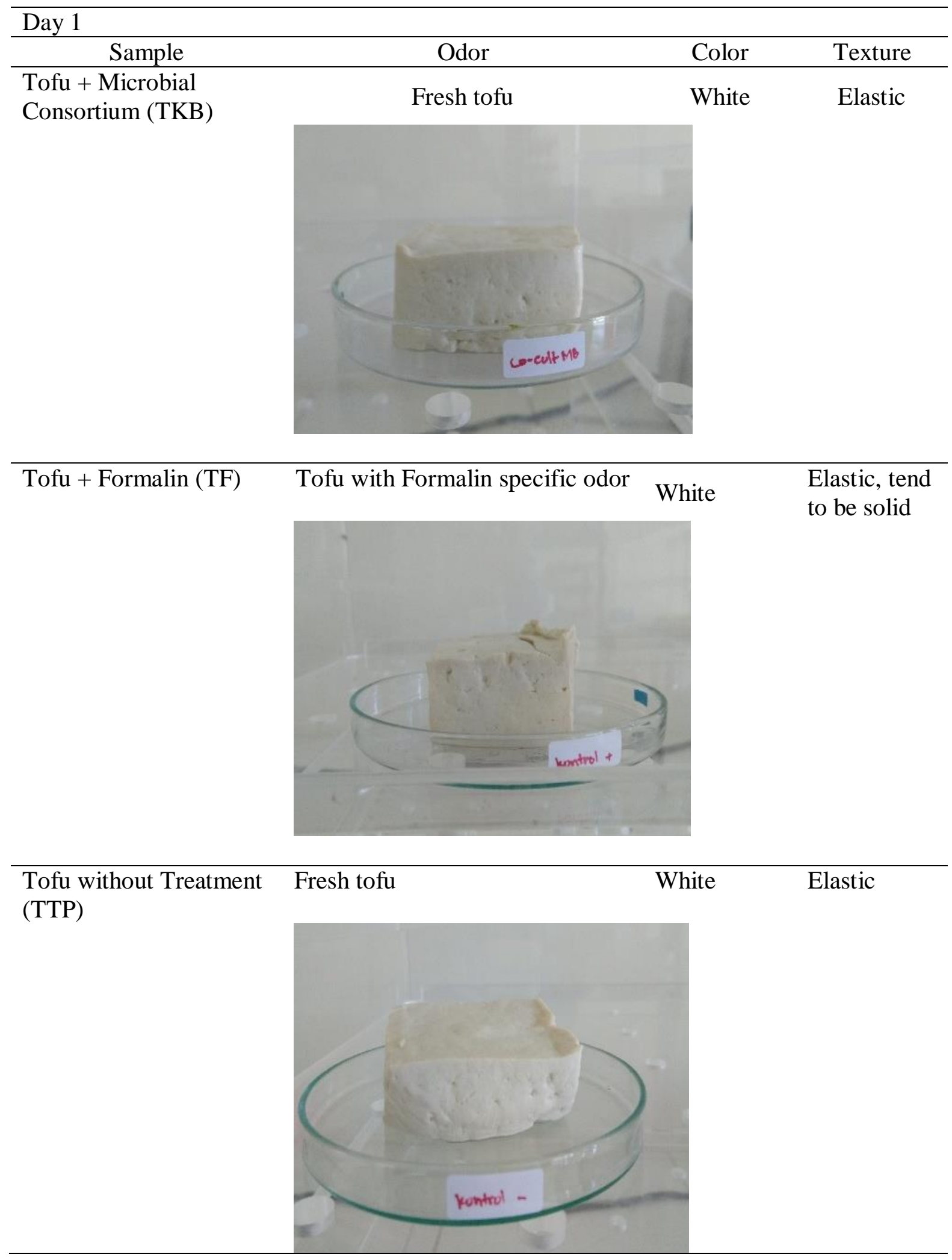




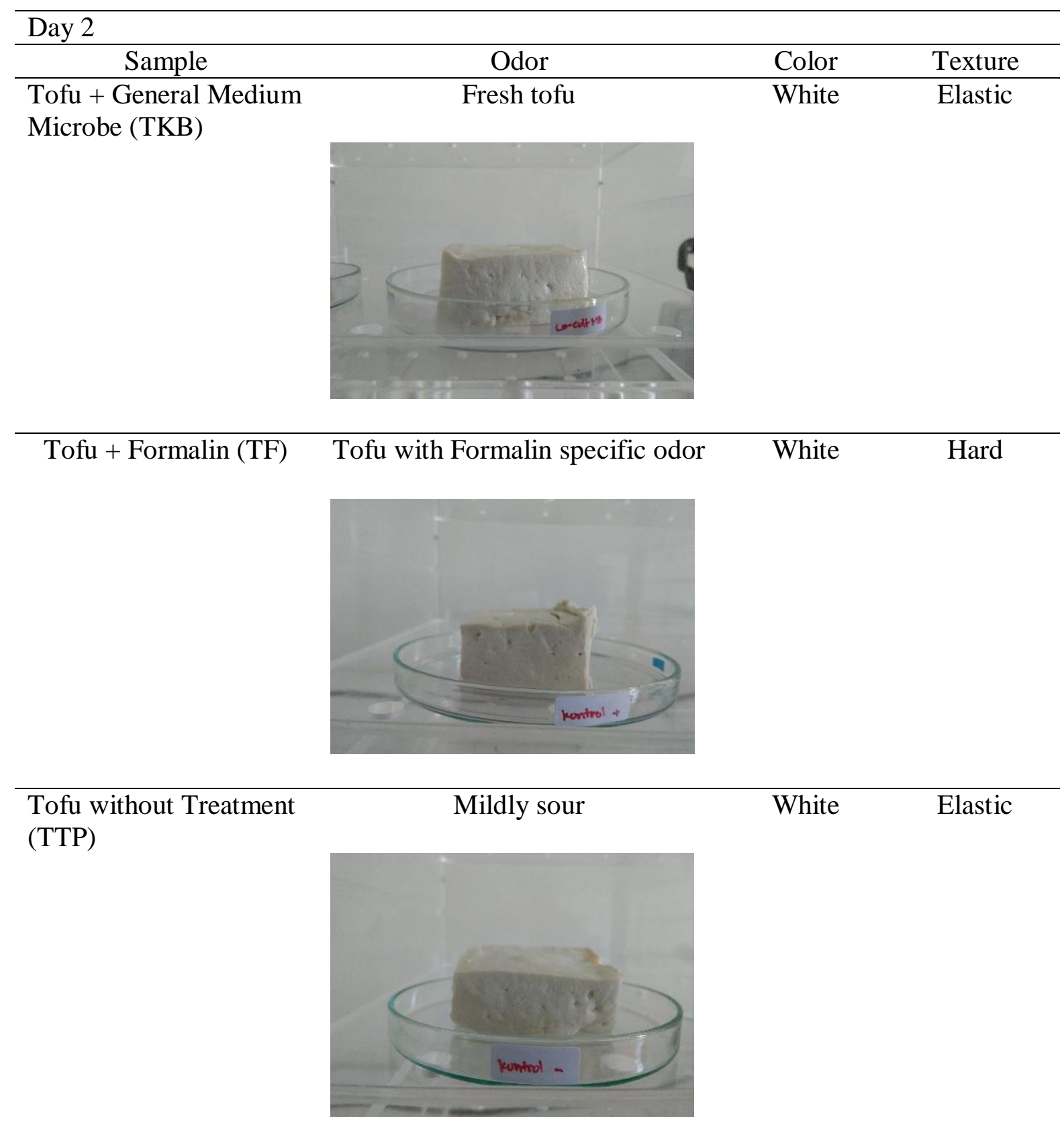

\begin{tabular}{lccc}
\hline Day 3 & & & \\
\hline \multicolumn{1}{c}{ Sample } & Odor & Color & Texture \\
\hline $\begin{array}{l}\text { Tofu + General Medium } \\
\text { Microbe (TKB) }\end{array}$ & Mildly sour & Yellowish & Elastic \\
& & & \\
& & & \\
& & & \\
& & & \\
& & & \\
& & & \\
\end{tabular}




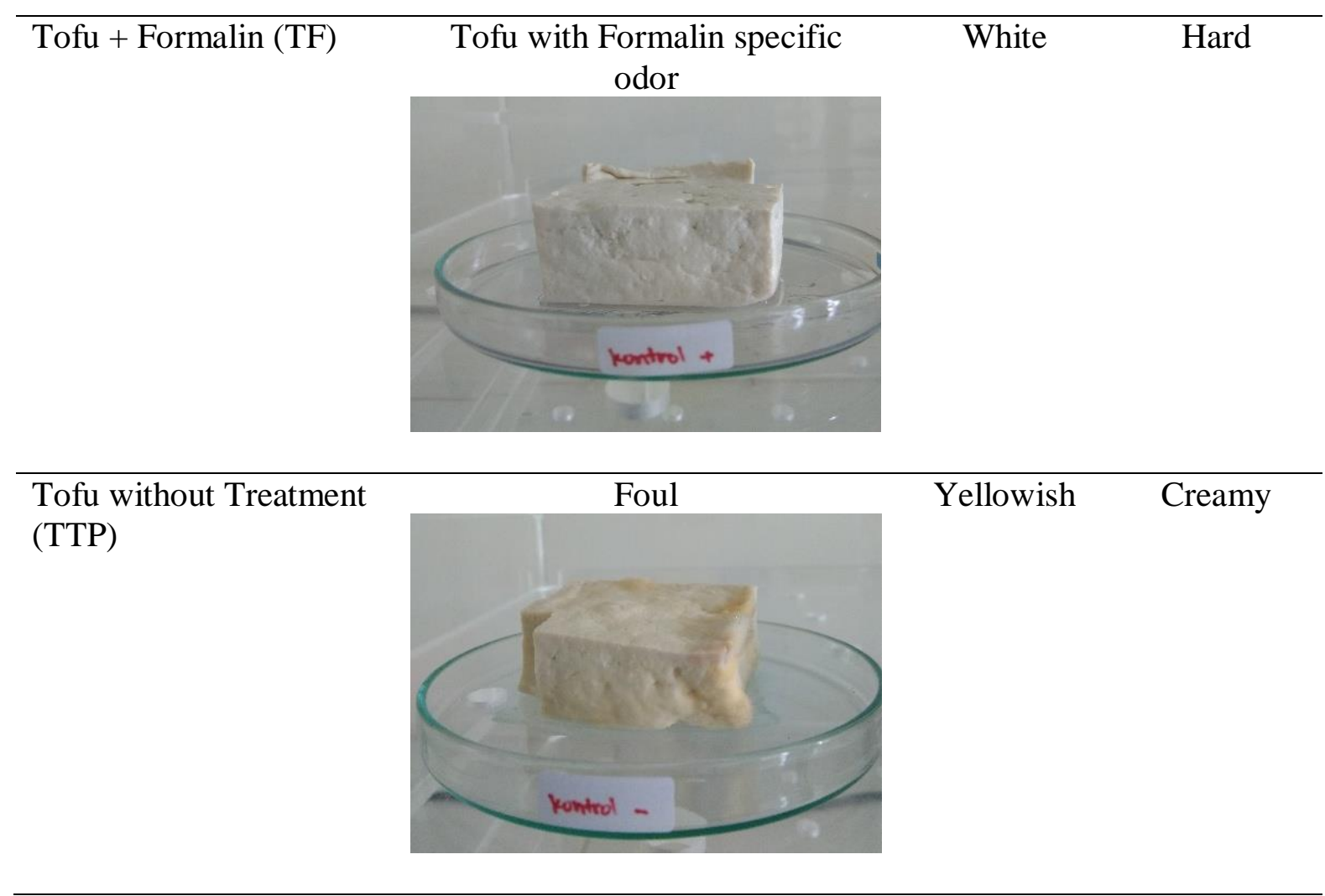

\subsubsection{Total Plate Count (TPC)}

The results show that the treatment of TTP had the highest microbial count, which was $25 \cdot 10^{6}(\mathrm{CFU} / \mathrm{mL})$. Whereas the TKB sample had the lowest microbial count, which was 6. $10^{6}(\mathrm{CFU} / \mathrm{mL})$. The TF sample showed a higher plate count than TKB, which was $9.10^{6}(\mathrm{CFU} / \mathrm{mL})$, as presented in Figure 1.

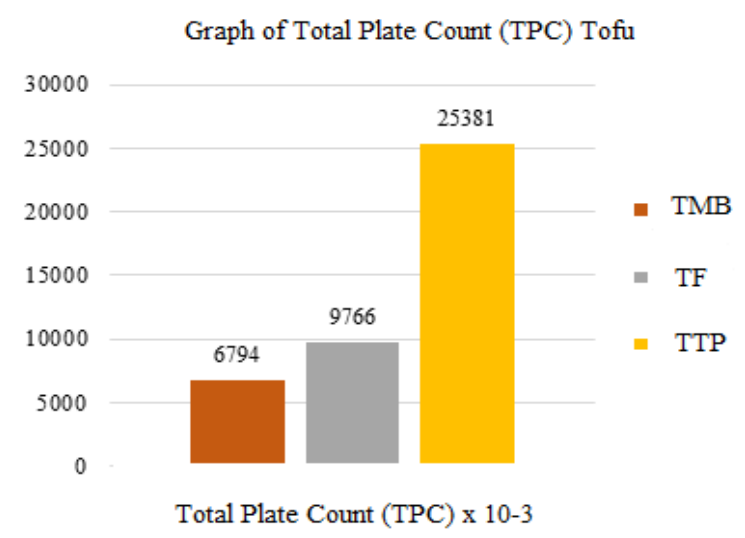

Figure 1. Total Plate Count (TPC) Graph 103 of Tofu with TKB, TF, and TTP treatment.

\subsubsection{Analysis of Crude Protein Content of Each Treatment}

Results of analysis of protein levels in each treatment, namely tofu immersed in microbial consortium (TKB) Tofu with formalin (TF), and untreated tofu (TT) samples. TF treatment has the highest protein value (14.66\%), compared to TKB (14.29\%) and TP $(12.88 \%)$, as presented in Table 2 .

Table 2. Analysis of Crude Protein Content of Each Treatment.

\begin{tabular}{clc}
\hline No & \multicolumn{1}{c}{ Sample Code } & \multicolumn{1}{c}{$\begin{array}{c}\text { Crude } \\
\text { Protein }(\%)\end{array}$} \\
\hline 1 & $\begin{array}{l}\text { Tofu Immersed in } \\
\text { Microbial }\end{array}$ & 14.29 \\
& $\begin{array}{l}\text { Consortium (TKB) } \\
\text { Tofu with formalin } \\
\text { (TF) }\end{array}$ & 14.66 \\
3 & $\begin{array}{l}\text { Tofu without } \\
\text { Treatment (TTP) }\end{array}$ & 12.88 \\
\hline
\end{tabular}




\subsection{Discussions}

The results of the study showed that the mangrove symbiont consortium microbe has potential for application as a natural food preservative Treatment with microbial consortium can maintain the color, smell, and texture of tofu. This result is different from the treatment of tofu with formalin, where the tofu texture turns solid. Formalin treatment resulted in the color of tofu, which remains white, but the formalin odor was very strong. Formalin is very dangerous if consumed by humans because this compound can damage body tissues and is highly toxic. The results of the analysis of crude protein levels of tofu samples showed that the samples of formalin treatment had higher protein content $(14.66 \%)$ compared to tofu samples treated with the microbial consortium (14.29\%). This indicates that formalin does not damage protein levels, despite its toxicity to living tissues.

Studies on natural ingredients of garlic and pandanus as food preservatives had been carried out (Cholifah et al., 2017). However, these natural ingredients are only able to preserve no more than one day or 23 hours. This result is different from that of the microbial consortium, which can preserve tofu for up to 3 days. Another method used for preserving tofu is using crab extract. Crab shells are potential as coagulants in the texture and sensory properties of tofu (Jun et al., 2018).

The results of the study of tofu with formalin and microbial consortium treatment showed that microbial consortium is more recommended to use than preserving using formalin. The microbial consortium in this study consisted of a synergistic combination of 4 different bacteria, i.e., Pseudomonas sp., Flavobacterium sp., Acinetobacter sp., $B$. subtilis Pseudomonas $s p$. is a pigmented and anaerobic bacteria. Classified as rhizobacteria, this species has a positive influence on plant growth by providing nutrients and hormones and can be antagonistic to bacteria and phytopathogenic fungi (Parjono, 2008).
The genus Pseudomonas is a microbe that can be found in almost all natural media and is resistant to compounds that inhibit the growth of other microbes, making it easily isolated. These bacteria can dominate the rhizosphere and develop rapidly, are gramnegative, motile, aerobic/facultative anaerobes (Pelczar \& Chan, 1986).

Flavobacterium sp. exhibits maximum activity between $\mathrm{pH} 8-10$ and is unaffected by the presence of metal ions. Non-ionic detergents are inhibitors of vigorous and irreversible activity (Brown, 2008). Flavobacterium $s p$. can be used to produce quercetin for industrial use, i.e., a type of flavonoid antioxidant found in edible plants (Atalay et al., 2018).

Bacteria from the genus Acinetobacter are aerobic, in the form of non-fermented gram-negative rods, and can be found in almost all types of environments (Rinsho, 2012). Bacteria from Acinetobacter $s p$., which is used in this study, has antimicrobial activity so that it is useful in inhibiting tofu decay.

B. subtilis is one of the antagonistic bacteria that is widely used in controlling soil-borne pathogens. The effectiveness of this species in controlling soil-borne pathogens in maize crops has been proven by several researchers, which means that $B$. subtilis is a strain that has antimicrobial activity (Suriani \& Muis, 2016). B. subtilis has the potential to be beneficial in inhibiting tofu decay.

The four microbes above are synergistic and are able to work together in one form of a consortium, which can form a community to produce compost products. The synergy of the four species of the microbial consortium is caused by the formation of bacterial communities, in which all species support each other and can synthesize products that can be mutually useful (Pringgenies et al., 2018). As elaborated in Deng \& Wang (2016), four factors are thought to occur in the microbial consortium, namely one member of the 
genus is able to provide one or more nutritional factors that cannot be synthesized by other members of the genus; one member of the genus which is unable to degrade certain organic matter will depend on members of the genus who can provide the products of degradation of certain organic materials; one member of the genus protects members of other genera that are sensitive to certain organic materials by reducing the concentration of said organic matter through the production of specific and non-specific protective factors.

\section{CONCLUSION}

It was concluded that four species of symbiotic bacteria of mangrove litter, namely Pseudomonas sp., Flavobacterium sp., Acinetobacter sp., Bacillus subtilis are microbial species with synergistic activities in a consortium. This microbial consortium has the potential to be a natural preservative for tofu.

\section{REFERENCES}

Brown, K.A. 1980. Phosphotriesterase of Flavobacterium sp. Soil Biology and Biochemistry, 12: 105-112. https://doi.org/10.1016/00380717(80)90044-9

Cholifah, N., L. Hendrarini, \& C. Amri. 2017. Pemanfaatan bawang putih dan daun pandan sebagai pengawet alami tahu ditinjau dari masa simpan dan tingkat kesukaan. J. Kesehatan Lingkungan, 9(1): 10-19. http://doi.org/10.29238/sanitasi.v9i1. 35
Jun, J., M. Jung, I. Jeong, G. Kim, J. Sim, S. Nam, \& B. Kim. 2018. Effects of crab shell extract as a coagulant on the textural and sensorial properties of tofu (soybean curd). Wiley Food Sciences \& Nutrition, 7: 547-553. https://doi.org/10.1002/fsn3.837

Matsunaga, N. 2012. Acinetobacter spp. Nihon Rinsho. Japanese J. of Clinical Medicine, 70(2): 236-242.

Pringgenies, D., I. Azmi, A. Ridho, \& R. Idris. 2016. Exploration of bacteria symbionts mangrove waste for the production of decomposer. In: International Conference on Coastal Zone" Osaka, Japan May 16-18, 2016. 13 p. http://eprints.undip.ac.id/53256/1/Exp loration_of_Bacteria_Symbionts_M angrove_Waste_for_The_Production _of_Decomposter.pdf

Pelczar, M.J. \& E.S.C. Chan. 1986. DasarDasar Mikrobiologi I. Hadioetomo HS, Imas T, Angka SL. Terjemahan dari Element of Microbiology. Jakarta UI Press. 443 p.

Suriani \& A. Muis. 2016. Prospek Bacillus subtilis sebagai agen pengendali hayati patogen tular tanah pada tanaman jagung. J. Litbang Pertanian, 35(1): 37-45. http://doi.org/10.21082/jp3.v35n1.20 16.p37-45

$\begin{array}{ll}\text { Received } & : 18 \text { September } 2019 \\ \text { Reviewed } & : 30 \text { October } 2019 \\ \text { Accepted } & : 29 \text { January } 2020\end{array}$

